\title{
AVRUPA BIRLIĞi'MDE BÖLGESELLEŞME VE BÖLGE YÖNETIMLERI SORUNU
}

\author{
Yrd. Doç. Dr. Mehmet Özel \\ Niğde Üniversitesi \\ Iktisadi ve Idari Bilimler Fakültesi
}

\section{Özet}

Ekonomik bir Topluluk olarak doğan Avrupa Birliği (AB), bugün bir siyasal birlik biçimi almanın nihai aşamasındadır. AB, bu belirtilen son şeklini alırken, Birlik içindeki (kurucu) unsurlar (ulus-devletler, eyaletler - bölgeler-, yerel yönetimler), kendi konumlarını sağlama alma, varlıklarını sağlam temeller üzerinde suirdürme uğraşı içinde bulunmaktalar. Doğaldır ki, Birlik de, bu unsurların siyasal ve/veya ekonomik gücüne göre bir şekil alacaktır.

Bu çalışma, AB'nin Birlik, ulus-devletler ve bölgeler temelinde uiç düzeyli bir siyasal yapılanma göstereceği iddiasındadır. Bu çerçevede çalışma, $A B$ içindeki bölgeselleşmeye yönelik kurumsallaşma ve bölge yönetimlerinin konumunu değerlendirmektedir. yönetimler.

Anahtar Kelimeler: Avrupa Birliği, bölgeselleşme, bölge yönetimleri, bütünleşme, yere!

\section{Regionalisation in the European Union and the Issues of} Regional Administration

\section{Abstract}

The European Union (EU), which was established as an economic structure, has turned out to be a political form eventually. The establishing elements of the EU, which are the nation-states, states, regions and local administrations, tend to strengthen their current positions and keep on their existence in a stronger position while the EU gets into today's form. Naturally, the Union is formed according to the political and/or economic power of these parties.

This study claims that the EU is a three-level political structure which consists of the Union, state and regions. In this frame, it discusses the state of regional administrations and regional institutionalisation within the EU.

Keywords: European Union, regionalization, regional administration, integration, local government. 


\section{Avrupa Birliği’nde Bölgeselleşme ve Bölge Yönetimleri Sorunu}

\section{Giris}

Avrupa'nın bütünleşmesi konusunun, İkinci Dünya Savaşı'nın hemen sonrasında Avrupa'da olanaklı en iyi banş düzeninin nasıl kurulacağına ilişkin yoğun tartışmalar biçiminde başladığı söylenebilir. Winston Churchill'in ileri sürdüğ̈̈ "federal bir Avrupa'nın kurulması" düşüncesinin gerçekleşme olasılığı kalmayınca, 1951 yılında Avrupa Kömür ve Çelik Topluluğu (AKÇT) kurularak, işlevselci bir bütünleşme teorisine dayanan dikkatli bir adım seçilmiştir.* Bu bütünleşme teorisi, Avrupa'da barışı sağlayacak kalıcı bir sisteme ulaşmak için, Avrupa Topluluğunu kuran üyelerin kendi aralarında yüzyıllarca sürmüş olan aşırı rekabete dayalı bir ilişkiler biçimi yerine, ekonomik sektörlerin adım adım birleştirilmesi suretiyle, bu ülkelerin önemli çıkarlarının karşılıklı gözetilmesini öngörmekteydi. Bu düşünceyle, ilk antlaşmadan hemen altı yıl sonra 1957'de Avrupa Ekonomik Topluluğu (AET) ve Avrupa Atom Enerjisi Topluluğu (AAET)'nun kurulmasıyla, söz konusu ülkelerin ekonomi-politiğinin bütünleşmesi önemli şekilde pekiştirilmişti.

$\mathrm{Bu}$ tarihten sonraki gelişmeler yeni-işlevselci bütünleşme teorisini doğrulamıştır. Üye devletlerin bütünleşme iradeleriyle desteklenen ve sürekli diğer sektörleri ağının içine çekerek, sonuçta, genel politik bütünleşmeyi son aşamaya ulaştıracak sektörel bir bütünleşmeye yol açacak olan yayılmazincirleme etkisi, konjönktürü 1992'deki Avrupa Birliğini Kuran Antlaşma'ya götürmüş ve sayılanı 15 'e ulaşan üye devletlerin egemenliklerinin hatırı sayılır

* Burada "yeni-fonksiyonalizm" teorisi pragmatik olarak biçimlendirilmiş olup, "olanaksal bütünleşik Avrupa"yı (l'Europa du possible) amaçlamaktaydi. Bir bütünleşme modeli olarak bu teori, federal ve fonksiyonel düşüncelerce şekillendirilmiştir. 
bir kısmını bu Birliğe aktardıkları bir devletler birliği (Staatenbund) oluşturulmuştur.

Maastricht Antlaşması'nın yürürlüğe girmesiyle, politik ve ekonomik açıdan özsel temelde daha da derinleşme amaçlanmıştır. Ayrıca bu Antlaşma, Avrupa'nın bütünleşme sürecinde yeni ve kesin bir devri başlatmıştır. Bu bütünleşme sürecinin, 1980'li yılların ortalanndan itibaren Tek Avrupa Senedi, Avrupa Ortak Pazarını Gerçekleştirme Programı ve Avrupa Ekonomik Alanı ile ekonomi, para ve politik alanda birliğin kurulması planları çerçevesinde kapsamlı bir şekilde ilerlediği söylenebilir.

Ancak, diğerleri yanında politik birliğin kurulması hiç de kolay gözükmemektedir. Çünkü Birliğin siyasal yapılanmasında ulus-devletler yanında diğer aktörler (eyaletler, bölgeler, yerel yönetimler) de söz sahibi olmak istemekte; diğer bir anlatımla, kurucu unsurlar arasına katılım yönünde yoğun talepte bulunmaktadırlar. Bu çalışma, AB'deki bölgelerin bu yöndeki uğraşlarını ve hukuksal-kurumsal gelişmeleri ele almaktadır. Burada "bölge"den kastın, devlet işlevleri açısından "ulus-devlet"in alt düzeyinde, buna karşın "yerel yönetim" düzeyini aşan siyasal-yönetsel birimlerin hepsi olduğunu belirtmekte yarar vardır.

Bu makale, Avrupa Birliği'nin gelecekte üç düzeyli bir yapılanma göstereceği, bir başka deyişle, Birlik, ulus-devletler ve bölgeler saç ayağı üzerinde temelleneceği iddiasını ileri sürmektedir. Bu noktadan hareketle, makale, Birlik çerçevesinde "bütünleşme" iradesinin dayanağını, bu iradenin bölgeler açısından anlam ve etkisini, bütüleşme çerçevesindeki işbirliğinin bölge temelinde mi yoksa federal temelde mi bir yapılanmada daha sağlıklı olacağı konularına 1şık tuttuktan sonra Avrupa birliğinde ilk kuruluş yıllarından bu tarafa yürütülen "ulus-altı yönetim düzeylerinin görmezden gelinemeyeceği" şeklindeki bir mücadeleyi ve bu uğraşın bugün için vardığı "üç düzeyli Avrupa" kavramlaştırmasını ortaya koymaktadır.

\section{AVRUPANIN BÜTUNLESMESI VE BÖLGECILIK}

"Avrupa'nın Bütünleşmesi" kavramı, Avrupa Topluluğu Kurucu Antlaşması'ndan çıkarılmaktadır. Bu Antlaşma'nın "Giriş”inde, “Avrupa halkları arasında sürekli daha sıkı işbirliği esaslarının yaratılması" söz konusu edilmektedir. Bu kavramın içeriği 2'nci maddede ortaya konulmuştur: Topluluğun görevi, "Topluluk dahilinde ekonomik yaşamda uyumlu ve ăgırlıkl bir değişimi (...), ekonomik etkinliklerde yüksek bir rekabet düzeyini, yüksek bir istihdam düzeyini, büyük oranda sosyal güvenliği, yaşam düzeyini ve kalitesini yükseltmek; üye devletler arasındaki bağlılı̆̆ ve dayanışmayı geliştirmek"tir (MARCOU,1998:59). 
Kuruluş gerekçeleri yukarıda belirtilen Avrupa Topluluğu'nda; diğer bir deyişle, bütünleşmeyi esas alan bir yapılanmada, ilk bakışta aynmlaşmayı çağgrş̧ıran "bölgecilik" kavramına nasıl yaklaşılmalıdır? Diğer bir anlatımla, Avrupa Topluluğu çerçevesinde bu kavramdan ne anlaşılmaktadır, bu kavrama ne tür işlevler yüklenmek istenmektedir?

Bölgeciliğin, uzun bir süre parçalanma yönünde bir kavrayış oluşturduğu söylenebilir. Ancak günümüzde bölgecilik artık, büyük oranda bir toplulukta kendi kendine yeterli birimlerin bütünleşebilmesine katkı sağlayabilecek bir ilke olarak anlaşılmaktadır (KNEMEYER,1994a:31). Diğer taraftan, bölgecilik, uluslar-üstü bütünleşme ile de ilgilidir. Diğer bir ifadeyle, ulus-üstü bütünleşme düşüncesi* ${ }^{*}$ başından beri ülke içi bölgecilik düşüncesi ile büyük bir yakınlık içerisinde olmuştur. Bu anlamda bölgecilik, bölgesel özerkliği artırıcı veya tamamen bölgesel özerklik ereği ile, merkezi yönetimin egemenlik iddiasının çözülmesine ilişkin bir uğraşı olarak da anlaşılabilmektedir. Burada bölge, bir bütünün altında ve yerelin üstünde, yerel düzey ile merkezi düzey arasında bulunan bir "bütün" olarak anlatılmak istenmektedir (THEISSEN,1996:32). Belirtmek gerekir ki, bu tür bir politik-yönetsel yapılanma federal bir nitelik kazanmamaktadır. Çünkü, bu yapı içerisindeki bölgeler, bir devlet niteliğine sahip değildir. Buna karşın, federal bir devlet yapısı içersindeki "bölgeler", devletsel bir nitelik gösterirler. Ayrıca, "bölgecilik" ile "bölgeselleşme" kavramlarının farkhlığının ayırdına da varılmalıdır. Bölgeselleşme, daha küçük birimlere doğru kararların aktarılması yoluyla, ulus-devletin öngördü̆̆ü adem-i merkezileşmeye ilişkin bir üst kavramı ifade etmektedir. Sonuç olarak, Avrupa bütünleşmesi ile bölgecilik, bir arada bulunabilen iki süreç olarak görülebilir (PUJOL, 1995:52).

Bölge ve bölgecilik kavramlarına, Avrupa'nın bütünleşmesi doğrultusunda şöyle bir yaklaşım benimsendiği söylenebilir: Birlik ve çeşitlilik, Avrupa'nın temel yasasıdır. Avrupa, "kültürel alan gücü"nü elde etmiştir; ancak Avrupa'nın, "politik ve ekonomik gücü"nü de kazanabilmesi için, bunun temel yasası olan "birlik ve çeşitlilik" arasındaki heyecanı da kazanması gerekir. Eğer Avrupa, bölümlerinin, halklarının, etnik yapılanının, taşra birimlerinin, bölgelerinin çok çeşitliliğini, "yaşam ilişkilerinin bütünlü̆̆̈̈̈'

* Bu düşüncenin arka planında, küreselleşme şeklinde kavramlaştırılan olguya ait nedenler olup; bu kavram, ekonomik, toplumsal ve politik bir bütünleşme hareketini ifade etmektedir. Bu hareket, hem devletler arasındaki hem de bölgeler ve kentler arasındaki ilişkileri oldukça yoğunlaştırmıştır. Küreselleşme hareketine paralel olarak, söz konusu birimler arasında sınır kavramının geçerliliğini giderek yitirmekte olduğu; diğer bir ifadeyle bütünleşmelerin, yerelleşme ve bölgeselleşme doğrultusundaki gelişmeleri sınırlandırmadığı; tersine, özendirici bir etkide bulunduğu ileri sürülmektedir (KELEŞ, 1999:55) 
örgüsüyle saramaz ise, kendi özgün niteliğini kaybeder. Avrupa için artık, "çokluk içinde birlik" anlayışının bilincine varılmalıdır (KNEMEYER, 1994b:17).

Günümüzde Avrupa'nın, daha küçük birimlere, bölgeselleşmeye doğru bir eğilim taşıdığı; bu gelişmenin ise, artan "tek Avrupa" düşüncesi ile yakın ilişkisi olduğu belirtilmekte ve bugün ulaşılan ya da amaçlanan "tek Avrupa" şeklindeki bütünleşmeye ve bu bütünleşmenin sonuçlarından biri olan ulusdevletlerin öneminin giderek azalması sürecine bir tepki olarak, değişik bölge halklarının ve etnik azınlıkların kendi farklılıklarının bilincine, eskisine göre daha fazla vardıkları dile getirilmektedir (PROBST,1994:131). Dolaysıyla bugün Avrupa'da var olan bölgecilik ve bölgeselleşme eğilimlerinin kaynağının burada aranması gerektiği söylenebilir.Bunun yanında, demokratik bir yönetim için Avrupa toplumları için çok şey ifade eden "yerellik" ve "yerinden yönetim" anlayışının da bölgecilik ve bölgeselleşme eğilimlerinde göz ardı edilemeyeceği vurgulanmalıdır.

Dolayısıyla Avrupa bütünleşmesi bölgeler açısından önemli etkiler yaratmaktadir.

\section{BÜTUNLEŞMENIN BÖLGELER UZERINDEK| ETKILER|}

Avrupa Birliğinin ilk antlaşmalarından olan Avrupa Kömür ve Çelik Topluluğu ile diğer Topluluk Antlaşmaları, yalnızca üye devletlere dayanıyordu ve eyalet, bölge, özerk topluluk gibi "alt-devlet”lerin katılım olanakları sadece üye devletler üzerinden öngörülmüştü. Ülke içerisinde önemli oranda bir özerklikten yararlanan Avrupa bölgeleri,* bu durumdan baştan beri rahatsızd. Örneğin, 1951 yılında mücadeleye başlayan Alman eyaletleri, ancak 30 yıl sonra, karar süreçlerine katılabilen politik aktörler haline gelebilmiştir (HIERL, 1995:82).

Bugün Avrupa Birliği'ne üye devletlerde var olan "bölgeler"in neredeyse yarısının ya demokratik bir siyasal-yönetsel yapıları yoktur veya çok zayıf bir yapıya sahiptirler. AB'nin istatistiksel bölümlenmesini gösteren NUTS II alanına uygun düşen 206 bölgenin neredeyse yarısını, genelde yönetsel bölgeler olarak sınıflandırmak gerekir. Zaten bu tür bir yapıdaki bölgeler, merkeziyetçi bir devletin aracı gibi görülebilir.

\footnotetext{
* Avrupa bölgeleri deyimi ile burada, Topluluğu oluşturan üye devletlerdeki "eyalet, bölge"gibi adlarla anılan ve yürütmeye ilişkin yetkileri yanında kimi yasama ve yargısal yetkilere de sahip olan ulus-altı yönetimler kasdedilmektedir.
} 
1980'li yılların başından bu tarafa, bir taraftan üniter ya da adem-i merkezileşmiş bir devlette bölgesel düzey doğrultusunda bir yetki aktanımı gerçekleşirken, diğer taraftan bölgeselleşmiş ülkeler olan İtalya ve İspanya'da merkeziyetçi devlet yetkilerinde bir yoğunlaşma yaşanmaktayd. Bu nedenle, bölgelerin sahip olduklanı yetkilerine paralel düşen resmi bir konum ortaya konamamaktadır. Diğer taraftan ise, politik düzeylerin iç içeliği artmaktadır. Ancak politik düzeylerin iç içeliğinin amaçlandığı yerlerde de kamusal düzeyler arasında net bir görev dağılımı başarılamamaktadır. Politik düzeyler arasında politik çözümleme, politik uygulama ve politik denetim konularında zorunlu olarak artması gereken işbirliği, Almanya ve Avusturya istisna tutulursa, bu düzeylerin şekli ve kurumsallaşmış uzun süreli bir işbirliği deneyiminin olmaması dolayısıyla özellikle zor görülmektedir.

1970'li yıllardan bu yana var olan durumu şu şekilde betimlemek olanaklıdır: "Batı Avrupa devletlerinin çoğunda politik (Regierungs-) ve yönetsel düzeyler arasında karmaşık bir ilişkiler ağı oluşturulmuştur. $\mathrm{Bu}$ ilişkiler ağı, devlet ile adem-i merkezi yönetimlerin etki alanlanı ayırımını ortadan kaldırmaktadır" (PINTARITS,1996:79).

Avrupa Birliği üye devletlerinin politik-yönetsel bölgeleri, Maastricht Antlaşması'na kadar hukuksal temele dayandırlmamıştı. Bu yüzden, Topluluk, bu tarihe kadar "bölgelere kör" olarak nitelendirilmiştir. Politik bölgelerin Avrupa düzeyindeki çıkar temsilcilerinden olan Avrupa Bölgeler Meclisi (Versammlung der Regionen Europas-VRE) ve Bölgeler Avrupası Konferansı, Avrupa Birliği Antlaşması'nın tasarı aşamasında Topluluk'taki bölgelerin saptanmasına yönelik isteklerini ortaya koymada başarılı olduklan söylenebilir (PINTARITS,1996:87). Diğer taraftan, Avrupa Parlamentosu da daha 1970'li yıllardan itibaren bölgelerin $\mathrm{AB}$ ve üye devletlerdeki konumlan ile ve ayrica bölgesel sosyal ve ekonomik dayanışmanın gerçekleşmesine ilişkin politikalarla ilgilenmiştir. Ayrıca Avrupa Birliği Komisyonu da, Avrupa bölgesel politikalan çerçevesinde giderek daha fazla bölgesel aktörlerle doğrudan ilişkiye geçerek; yerel ve bölgesel üst-birlikleri, resmi olmayan bir biçimde kendi politik çözümlemesi ve yapılanması içine dahil etmiştir.

Roma Antlaşması'nın giriş bölümünde, üye ülkelerin ekonomik bütünleşmelerinin başarıya ulaşması için, bölgeler arasındaki ekonomik gelişme farklarının giderilmesi gerektiği belirtilmişti. Buradan hareketle, 1975 yılında bölgesel kalkınma politikasının temelini oluşturan Bölgesel Kalkınma Fonu kurulmuş ve bu fondan yardım alacak bölgeler, Topluluğun gayri safi yurtiçi hasılasının \%75'inin altında kalan yerler olarak tanımlanmıştır (TC.Başbakanlık,1999:105). 1987'de imzalanan Avrupa Tek Senedi ile Roma Antlaşması'na $130 \mathrm{D}$ maddesi eklenmiş ve bu madde çerçevesinde $A B$ 'nin bölgesel politikaları kapsamında kullanılmak üzere üç fon oluşturulmuştur: 
1.Avrupa Bölgesel Kalkınma Fonu, 2. Avrupa Sosyal Fonu, 3.Avrupa Tarımsal Yön Verme ve Güvence Fonu.

Avrupa'da yaşanan gelişmeler göstermektedir ki, Avrupa'nın bütünleşme sürecinin derinleşmesi, bu sürece katılan bir çok ülkede siyasal ademi merkeziyeti de içerecek şekilde bir yerelleşmeyi beraberinde getirmektedir. Bu doğrultuda yurttaşa daha yakın yeni bir yönetim alanı oluşturulmak istenmektedir. 1950'li yıllarda Avrupa Topluluğu içinde sadece Almanya, sağlam bir "bölgesel" yapıya sahipti. Bu örneğe çok yakın bir tarihte Belçika, Italya ve Fransa katılmıştır. Portekiz, Hollanda ve diğer Topluluk ülkelerinde yavaş da olsa bir bölgeselleşme gerçekleşmektedir. Bu gelişmeler göstermektedir ki; Avrupa bütünleşmesi ve bölgeselleşme bir çelişki oluşturmamaktadır. Bu iki sürecin daha çok, bir madalyonun iki yüzü gibi olduğu; devletin, bütün sorunları çözecek yegane yönetim düzeyi olarak yetkili kılınması görüşünün, artı savunulamayacağı ileri sürülmektedir (PUJOL, 1995:49).

Avrupa Birliğini Kuran Maastricht Antlaşması'nın yürürlüğe girmesiyle, Avrupa'nın bütünleşme sürecinde yeni ve ana çizgileri belirginleşmiş bir dönem başlamıştır. Bu bütünleşme süreci, 1980'li yılların ortalarından itibaren Tek Avrupa Senedi, Avrupa Ortak Pazarını Gerçekleştirme Programı ve Avrupa Ekonomik Topluluğunu gerçekleştirme aşamalarından, Ekonomik, Politik ve Para birliğinin kurulması planları çerçevesinde; diğer bir deyişle, tek ekonomi, tek para birimi ve söylenmesi henüz erken gibi gözüküyor olmakla birlikte, tek devlet şeklinde ilerlemektedir.

$\mathrm{Bu}$ bütünleşme adımları sonucu Avrupa Birliği'nin, üye devletler ve bunların bölgesel ve yerel yönetimleri karşısında politik ve ekonomik açıdan önem kazandığı açıktır. Ulus-üstü birimlerin (Birliğe ait örgütlenmelerin) görev çeşitliliğinin süre giden genişlemesi yüzünden, Birliği oluşturma sürecine karşı harekette bulunacak aktörlerin sayısı artmaktadır. Söz konusu aktörler çerçevesinde 1980'li yıllarda özellikle Alman eyaletleri ve onlann desteğindeki diğer üye devletlerin politik eylem yeteneğine sahip bölgeleri (ki bunlar, Avrupa düzeyinde daha fazla ortak karar alma olanaklanna sahip olma uğraşı içerisindeler. Aynca bunlara 1990'lı yıllarda Avrupa yerel yönetimleri de katılmıştır), Topluluk bütünleşmesine kendilerinin daha güçlü bir şekilde dahil edilmesi girişimlerinde bulunmuşlardır (RAICH,1995:16).

Avrupa Birliği ülkelerindeki bölgeselleşme ve federalleşme süreçleri yanında özellikle Avrupa düzeyinde ulus-üstü aktörlerin önemini artıran Topluluk-içi gelişmeler olmuştur, ki bu sürecin de bölgecilik eğilimlerini güçlendirdiği söylenebilir. Öncelikle burada 1980'li yıllarda Topluluğun etkinlik alanını genişletmesi belirtilebilir. $\mathrm{Bu}$ genişleme, hem Antlaşma 
hükümlerinin geniş bir şekilde yorumlanmasıyla, hem de 1986 tarihli Tek Avrupa Senedi'nin yaptığı gibi, Antlaşma'nın resmi yolla düzeltilmesi biçiminde yapılmıştır. Böylece Topluluğun eylemleri, adım adım "bölgesel politika" alanına kadar yaygınlaşmıştır. İkinci bir gelişme, çevre politikası ile araştırma ve teknoloji politikası alanlarında olmuştur. Bu alanlarda Topluluk, Tek Avrupa Senedi ile açıkça yeni yetkiler kazanmıştır. Kısmen de olsa bölgesel sonuçlar doğuran alanlara Topluluk görev sahasının bu şekilde genişlemesi, Topluluk politikalanyla ilgilenenlerin sayısının artması ve böylece Topluluk sisteminin değişik düzeyleri arasındaki karşılıklı bağımlılığın ve iç içeliğin artması anlamina gelmektedir. Diğer taraftan Topluluk, artan bir oranda bölgesel beklenti ve isteklerin, örneğin bölgesel politika, araştırma ve teknoloji politikalarında teşvik programlarına katılma açısından, muhatabı haline gelmektedir. Bu bağlamda önemli bir diğer gelişme, Topluluk kurumsal yapısının farklılaştırılmasıyla gerçekleşmiştir. Buna göre, AB Bakanlar Konseyi'nin çalışma gruplarının sayısı artırılmış ve ayrıca ulusal memurların ağırlıklı olarak görev aldığı komiteler aracılığıyla $\mathrm{AB}$ Komisyonu'nun kararları üzerinde denetim artmış ve böylece bu kararların bağlayıcılı̆g ulus-devleti aşarak bölgelere doğru genişlemiştir (HRBEK / WEYAND, 1994:82).

Diğer taraftan ise bu gelişmeler, Topluluğun federatif ve bölgeselleşmiş ülkeleri için özel bir zorluk meydana getirmiştir. Topluluğun eylem alanının, tipik bir şekilde bölgelerin yetki alanlarına giren konulara doğru genişlemesi, bölgeler için ilk planda bir fırsat anlamına gelmemiş; tersine her şeyden önce onların özerk hareket alanlarının esaslı bir şekilde sınırlanmasını beraberinde getirmiştir.

Bütün bu gelişmeler, Avrupa Bütünleşmesinin, ulus-devletlere mi, yoksa bölgelere mi dayalı olacağı tartışmasını öne çıkarmıştır.

\section{3. “BÖLGELER AVRUPASI" DEVLETLER AVRUPASI" \\ VEYA MULUSAL}

"Bölgeler Avrupası" (Europa der Regionen) ve Ulusal Devletler Avrupa'sı" (Europa der Vaterlaender) kavramlanın açıklamaya geçmeden önce hemen başta "Vaterland" (anavatan) kavramına açıklık getirmek gerekirse, bu kavram, "atalar ülkesi" anlamına gelmekte olup; çoğunlukla yurtseverlik (Patriotismus) duygularıyla bağlantılıdır. Örneğin biz, ulusal futbol takımının galip geldiğinde sevindiğimizde, bu anlamda "yurtsever"izdir. Diğer taraftan bu "yurtseverlik", milliyetçilik içinde istenmeyen bir biçim de alabilir. Bu nedenle, "Europa der Vaterlaender" düşüncesinin 'sorunlu' bir düşünce olduğu söylenebilir; çünkü bu, $\mathrm{AB}$ üyelerinden beklenilmesi gereken, bütünleşme 
yönündeki temel düşünceye ve Topluluğun anlamına karşıttır (HALLIGAN, 2001).

Avrupa bütünleşmesi ile kapsamlı bir bölgeselleşmenin gerekliliği arasındaki diyalektik ilişkiyi, bölgecilere göre, özellikle Avrupa'nın büyük ulusal devletleri belirginleştirecektir. Çünkü, bölge yönetimini yeğleyenlere göre, bu ülkeler, demokratik ve bireysel öz gelişimi harekete geçirecek bir büyüklüğe sahip olmaları dolaysıyla, Avrupa'nın diğer ülkeleriyle dengeyi bozabilirler ve geçmişin emperyalist hastalığını beraberinde getirebilirler (THEISSEN,1996:33).

Avrupa'da ortaya çıkan çeşitli bölgeselci, ulusalcı ve ayrılıkçı hareketler, ulus devletlerin yapılarının yetersizliğinin bir ifadesi olarak görülmektedir. Bölgecilik düşüncesinin ortaya çıkış sebepleri olarak; Batı Avrupa ülkeleri içinde savaş riskinin ortadan kalkması, politik kararlara etkin bir şekilde katılma isteği ve ayrıca artan bir kimlikleşme arzusu sayılabilir. Kendi kimliğine sahip olmaya ilişkin çaba, Katalonya, Bask gibi tarihi bir geleneğe sahip olmak dolaysıyla kendine özgü bir halk özelliği gösteren ya da başka bir halka aitlik şeklinde bir algının olduğu bölgelerde özellikle güçlüdür (THEISSEN,1996:34).

Diğer taraftan, bölge ile ulusal devlet arasındaki ilişki biçimi de bu bağlamda önemlidir. Buna göre bölge ile ulus-devlet arasındaki ilişki şu biçimde tanımlanabilir: Merkezi yönetimin, ulusal düzeyde sadece homojen alanların varlığını vurgulaması, mevcut devlet- ve toplum sisteminin merkezileşme eğilimleri göstermesine yol açmakta; bu durum da politik bir tepki-kuvvetine ve aynı şekilde başka biçimde bir mekansal biçimlendirme rekabetine yol açmaktadır (LUVERA, 2001). Kısaca, mekansal (yerel) düzeyde temel şekillendirici aktörün devlet mi yoksa bölgeler mi olacağı hususunda yetki tartışması gündeme gelmektedir.

Belirtilen bu durumlardan hareketle, Avrupa'nın güç dengesini ve buna bağhı olan barış ortamını bozucu etkiden kaçınılması bağlamında, De Gaulle'ın "Europa der Vaeterlaender" (Ulusal Devletler Avrupası) kavramı ile "Europa der Regionen" (Bölgeler Avrupası) biçimleri karşılaştırılmaktadır. "Bölgeler Avrupası", bütünleşmenin yürütücüsü olarak, şimdiye kadar var olan üye devletler yerine, Avrupa'nın bütün bölgelerinin federal bir biçimde birleştirilmesini öngörmektedir. Bölgeler Avrupası modelinde bölgelerin, kimliklerini korumada ve bütünleştirici önemdeki çıkarlarını gerçekleştirmede üç etkinlik düzeyi bulunmaktadır: Ülke-içi irade oluşum sürecine katılım, Topluluk düzeyindeki karar alma sürecine doğrudan katılım ve bölgelerarası işbirliği (SCHMIEDHUBER,1995:34). "Bölgeler Avrupası" düşüncesi iki 
dönemsel bölüme ayrlabilir (THEISSEN,1996:34):Bölgeler Avrupası (Europa der Regionen) ve Bölgelerle Avrupa (Europa mit Regionen).

"Bölgeler Avrupası" modelinin, bugün için kabaca belirginleştiği söylenebilir. Burada temel düşünce, bölge olgusunu, bugünkü Avrupa bütünleşmesi sürecinin geliştirdiği ve buna bağlı olarak yeni bir özerk yönetim basamağının gelişmekte olduğunu ve böylece Avrupa alanında geleceğin üç ayaklı federalizminin oluşturulabileceğidir (MARCOU,1998:73).

"Bölgeler Avrupası" kavramı, Bayern eyaletince geliştirilmiş olup; bu kavramın ve ayrıca bu düşüncenin 'Kültürler Avrupası' yönünde bir kurumsallaşmayı da içerdiği belirtilmektedir (GOPPEL, 1995:129).

"Bölgeler Avrupası" kavramının uygulamaya konulabilir şekilde yeterince açık olduğu bugün için söylenemez. Bu kavram, temelde üç yaklaşım tarafından şekillendirilmektedir: İlk olarak; en geniş anlamda "Bölgeler Avrupası", gelecekte bölgelerin, Avrupa bütünleşmesinin temel yapı taşı olarak ulus-devletlerin rolünü üstlenmeleri gerektiği düşüncesine dayanmaktadır. İkinci olarak; bölgelerin ulus-üstü düzeyde daha fazla katılım firsatlan elde etme ve ayrica üçüncü (ulus-altı) düzeyde politik eylem birimleri olarak kabul edilmeleri ve bu hususun Topluluk Antlaşması kararlarında belirtilmesi isteklerini içermektedir. Üçüncü olarak; Avrupa'da ulus-altı yerel birimler arasındaki işbirliğinde devlet sınırlarını aşabilecek işbirliği biçimlerinin kabul edilebilirliğini göstermektedir (RAICH,1995:25).

“Bölgeler Avrupası" ilkesi, Avrupa'nın bütünleşme sürecinin getirdiği devlet yetkilerinin erimeye devam etmesi durumuna karşı koymada ve kimliğin korunmasında bir araç olarak görülmektedir (KNEMEYER,1994b:18). Çünkü, Avrupalılann politik ve kültürel kimliklerinin esas olarak kentler ve bölgelerle özdeşleşmiş olduğu ve dolaysıyla Avrupa'nın bütünleşmesi idealini gerçekleştirmek için en elverişli ortamın yerel ve bölgesel yönetimlerin serbestçe seçilmiş temsilcileri yardımıyla oluşturulabileceği ileri sürülebilir (KELEŞ, 1998:7).

Şunu da belirtmek gerekir ki, "Bölgeler Avrupası" modeli, günümüzdeki gelişmeler dikkate alınarak, "karşılaşılan güçlüklerle baş etmede veya yeni fırsatlardan yararlanmada ulus-devletin ortalama olarak büyük, buna karşın [temel ve tarihsel bir komün olarak] kentlerin ise küçük kalması" gerekçeleriyle de öne çıkarılmak istenmektedir (GERSTL, 1999).

"Bölgelerle Avrupa" modeli ise, var olan ulusal devletlerin federalleşmesinden hareket etmektedir. Belirtmek gerekir $\mathrm{ki}$ bu yolun gerçekleşmesi, Fransa, İtalya ya da Birleşik Krallık'ın yüzyıllan aşan üniter geleneği karşısında oldukça zor görünmektedir. Bununla birlikte, en azından güvenlik politikası nedenlerinden dolayı mevcut ulus-devlet yapılanının 
dağılmasını öngörmemektedir. Bu nedenle, bu ikinci modelin amacı, Avrupa Birliği, ulus-devletler ve bölgelerden oluşan üç kademeli (düzeyli) bir Avrupa kurmaktır. Bundan dolayı "Bölgelerle Avrupa" kavramlaştırması, "Bölgeler Avrupası" kavramına göre 'daha kabul edilebilir' olarak nitelendirilebilir.

Avrupa bütünleşmesinin daha sağlıklı gerçekleştirilmesi açısından siyasal-yönetsel birimlerin gereksinim duyduğu "işbirliği”, acaba bölgecilikte mi yoksa federalizmde mi daha sağlıklı işler? Geleceğin Avrupa yapılanması bunlardan hangisine dayanmalıdır?

\section{BÖLGECILIKTE VE FEDERALIZMDE IŞBIRLIĞ|}

Geleceğin Avrupa Birliği'nin gerçekleşmesinin, üst derecede federal bir yapıda örgütlenmekten geçtiği; bunun da "Bölgeler Avrupa'sı" modeli çerçevesinde üç düzeyli (Birlik, ulusal devletler ve bölgeler) bir yapıyı öngördüğü belirtilerek; ancak bu üç düzeyin birlikte hareketiyle, merkezi eğilimlere ve ayrılıkçılığa (separatizm) karşı konabileceği; dolayısıyla takip edilecek altın yolun, çeşitlilik içinde teklik (çokluk içinde birlik) olduğu görüşü, bölge temsilcileri ve/veya taraftarlarınca genelde ifade edilmiştir (GOPPEL, 1995:5).

Avrupa Parlamentosu'nca 18 Kasım 1988'de kararlaştırılan “Topluluk Bölgeselleşme Şartı"nda, kamu görevleri yerine getirilirken ve özellikle kendi bölgelerinde yürütülen görevlere makul bir şekilde katılmada bölgelerin yetkili olması istenmekteydi. Şarta göre, bu katılımın, merkezi devletin geleneksel dikey modeli yerine, yatay eşgüdümleme modelini esas almış (ast-üst ilişkisi olmayan) bir "işbirlikçi bölgecilik" esasına dayanması gerekiyordu.

Avrupa Parlamentosu'nun kullandığı "işbirlikçi bölgecilik" kavramının anlamı, "işbirlikçi federalizm" kavramı ile benzerlik kurularak çıkarılabilir (THEISSEN,1996:37). Dolaysıyla burada önce "işbirlikçi federalizm” kavramı ele alınmahıdır.

Federalizm, bir ülke içerisinde eşit haklara ve serbestliğe sahip parçaların, müdahalede bulunabilen politik bir bütüne bağlandığı, bölümlenmiş bir devletin örgütlenme ilkesini ifade eder (LAUFER/MUNCH,1997:14). "Işbirlikçi federalizm" kavramı ise, modern devlette ortaya çıkan görevleri, hayati alanlardaki görevleri ele almakta ve devlet örgütünün ussallığını, teknolojikliğini, hizmet performansını, diğer bir ifadeyle sosyal bilimler bağlamında "verimliliğini" söz konusu etmektedir.

Bu sistemde, işbirliği bağlamında iki düzey kullanılmaktadır: Yatay işbirliği düzeyine eyaletler, görevlerini yerine getirmek için katılmaktadırlar. Dikey düzeyde ise, bir ya da daha fazla eyalet ile genel yönetim arasındaki 
ortak görevlerin yerine getirilmesi bağlamında ve ayrıca yönetsel kuruluşlarla eşgüdümlü önlemler çerçevesinde işbirliği gerçekleşmektedir.

"Işsirlikçi Bölgecilik" çerçevesinde belirtmek gerekir ki, federal devletlerle karşılaştırıldığında bölgeselleştirilmiş devletlerdeki "bölgeler", bağımsızlık konusunda, özellikle dışa karşı bağımsızlık konusunda doğal olarak daha az haklara sahiptir. Buna rağmen, bu tür devletlerde de işbirliğine dayalı olarak görevleri yerine getirecek bir sistem kurmak olanaklı görülmektedir. İşbirlikçi bir bölgecilik anlayışı ile anayasal yapısıs şekillenmiş olan İtalya buna örnek olarak gösterilebilir. $\mathrm{Bu}$ ülkede, iki adem-i merkezileşme aşamasına (1968/71 ve 1975/77) bağh olarak, bölgesel düzeyin artan boyutta hem devletin yasama sürecine hem de yürütme (yönetim) sürecine dahil edildiği bir sistem ortaya çıkmıştır. Özellikle Avrupa Hukuku alanında İtalyan bölgeleri bugün hem irade oluşumuna hem de yürütülmesine çeşitli meclisler aracılığıyla katılmaktadırlar.

Avrupa birliği yapılanmasında önemli aktörler olarak öne çıkmaya başlayan bölgelerin, acaba hangi aşama ve süreçler sonucu bu güne geldikleri sorusunu yanıtlamak, bölgelerin bu alanda yaptıkları mücadelenin düzeyini ortaya koymak açısından önem arz eder.

\section{BÖlgeLERIN AVRUPA DUZEYINDE TEMSILININ GERISIM SURECI}

Avrupa düzeyinde bölgesel çıkarların ilk kurumsallaşması, Avrupa Konseyi'nin Parlamenterler Meclisi'nde söz konusu edilmiştir. Avrupa Konseyi'nde, Avrupa'nın bu tür eyalet ve bölgeleri neredeyse hiç temsil edilmemekteydi; bu yüzden, bu kurumsallaşmanın Avrupa Birliğini aşan önemde bir role sahip olduğu söylenebilir.

Avrupa Konseyi'nin, Avrupa'nın birey ve halkları arasında "sürekli daha sıkı bir topluluk yaratma" görevi, daha 1950'li yıllarda yerel yönetimlerin ve bölgelerin de "demokratik bir toplumun yapı-blokları" olarak kabul edilmesi gerektiği biçiminde yorumlanmıştı. Bu yüzden 1952 yılında, yerel ve bölgesel sorunlar için kendine özgü özel bir parlamenter komite kuruldu; ancak bu komite daha sonra 1954 yılında sadece "yerel yönetim sorunları komitesi"ne dönüştürülmüş ve böylece "bölgesel boyut" ortadan kaldırılmıştır. Daha sonra "Yerel Yönetimler Sürekli Konferansı" adını alan bu kurum, 1975 yılında "Yerel Yönetimler ve Bölgeler Daimi Kongresi"ne dönüştürülmüştür. Bu kongrenin görevi, Avrupa Konseyi Bakanlar Komitesi'ne ve Parlamenterler Meclisi'ne yerel yönetimleri ve bölgeleri ilgilendiren konularda görüş ve tavsiyelerde bulunmaktır. 
1994'e kadar "Daimi Konferans" statüsü devam eden Avrupa Yerel ve Bölgesel Yönetimler Kongresi'nin temel amacı, yerel-bölgesel yönetimleri Avrupa Birliği sürecine ve Avrupa Konseyi çalışmalarına katmak, yerel ve bölgesel demokrasiyi kurup, işlerliğini artırmak ve özellikle Avrupa'da bölgelerarasındaki işbirliğini güçlendirmektir (ERBAY / YENER,1998:17).

Avrupa düzeyinde özellikle bölgelere ilişkin gelişmelerin yetersizliği dolaysıyla, 1985 yılında bölgeleri temsil eden bağımsız bir yapılaşmaya, Avrupa Bölgeler Konseyi'nin kurulması yoluna gidildi. Bu komite daha sonra Avrupa Bölgeler Meclisi adını almıştır.

Avrupa Bölgeler Meclisi, güçlü ve özerk bölgelerce yönlendirilmektedir. $\mathrm{Bu}$ meclis, Parlamenterler Meclisi ve Konsey Bakanlar Komitesi yanında üçüncü bir ayak olarak ve kendine özgü bir meclis biçiminde Avrupa Konseyi kurumsal yapısı içinde eşit ve aynı yetkide bir konuma sahip olmak için diretmektedir.

Yerel ve Bölgesel yönetimlerin etkinlikleri, Avrupa Konseyi'nin her konudaki politikalarında güçlü bir etki kazanmıştır. Avrupa Konseyi, Avrupa bölgeciliğini, halkın katılımı ve demokrasi için özel bir öneme sahip olan uygun bir araç olarak görmekte ve ayrica Avrupa bütünleşmesinin temeli ve aynı zamanda azınlıkların korunmasının en üstün biçimi olarak kabul etmektedir; yine Konsey, Yerellik ilkesini (Subsidiaritaet) yerel ve bölgesel düzeye uygulamaktadır.

Bölgesel alana ilişkin Avrupa Topluluğu çerçevesindeki gelişmelere kısaca bakılacak olur ise, Avrupa Parlamentosu'nun da bölgeleri desteklemeye yönelik 1970'li yıllardan başlayan girişimleri söz konusudur. Avrupa Parlamentosu 1988 yılında, "Topluluk Bölgesel Politikası ve Bölgelerin Rolü / Topluluk Bölgeselleşme Şartına Ek" kararında üye devletler tarafından bölgelerin sınır-ötesi işbirliğinin geliştirilmesini, ulusal düzeydeki bölgeselleşmeye yönelik en alt düzeydeki ilkeler (beklentiler) olarak kabul etmiştir.

Avrupa Topluluğu üye devletlerinde 1982 yllından itibaren artan bir şekilde adem-i merkezileşme ve bölgeselleşme uygulamaları görülmektedir. Bu uygulamalar, "Bölgeler ile Avrupa" modeline yönelik bir girişim olarak yorumlanabilmekle birlikte, Topluk devletlerinin gerçek anlamda federalleşmesinin işaretleri olarak değerlendirilememektedir. Ancak bölgeselleşme yönündeki gelişmeler de "federalizmin küçük kardeşi" olarak görülmektedir. Buna göre bölgecilik, bir ön-biçim olabilir veya federalizmden bağımsız bir biçim olarak varlığını devam ettirebilir. Ancak "Bölgelerle Avrupa" modeli taraftarları, bölgeselleşmenin ötesinde bir durumu ifade eden federalizme karşıt olarak, her koşulda bölgeselleşmiş bir Avrupa yaratma amacındalar. 
$\mathrm{Bu}$ amaca ulaşmak için, sadece ulusal düzeyde bölgeselleşme tartışmalarını yürütmek yeterli görülmemekte; Avrupa'da üç düzeyli bir yapıya ulaşmak için ve ulusal devletler tarafından, Avrupa bütünleşmesinin, bölgesel düzey ile doğrudan bağlantı sağlanarak gerçekleşmesi için, "bölge" konusunun Avrupa düzeyine de taşınması zorunlu görülmektedir. Bu bağlamda, Bölgeler Avrupası kavramlaştırması çerçevesinde, bölgelere daha fazla ağırlığın verilmesi istenmekte; diğer taraftan, bölgelerin görevinin de, Avrupa'nın ortak büyümesini "içerden" destekleyecek olan politik, kültürel ve özellikle ekonomik işbirliğini derinleştirmek olduğu belirtilmektedir (http://www.spdschleswig-holstein.de, 2000). Bölgelerin Avrupa düzeyi ile bütünleşebilmelerinde temel katılım alanları olarak da, Avrupa Güvenlik ve İşbirliği Örgütü (OSZE), Avrupa Konseyi (Europarat) ve Avrupa Birliği sayılmaktadır (THEISSEN,1996:36).

Aşağıda Avrupa Birliği içerisindeki bölgesel gelişmeler ele alınmaktadır.

\section{MAASTRICHT ANTLASMASI SONRASI BÖLGELER}

Avrupa Birliği'ni oluşturan uluslar arasında ve bu ulus yurttaşlarının milliyetçi duyguları ile bir uluslar-üstü egemen politik erke bağlanma duyguları arasında bir dengenin oluşması açısından kimi Avrupa devletlerince (örneğin, Fransa ve Büyük Britanya) onaylanması oldukça zor gerçekleşen Maastricht Antlaşması (Le GOOF, 1997:100) ile birlikte, bölge ve yerel yönetim birimlerinin konumunda önemli bir yenilik olmuştur. Bu yenilik, söz konusu birimlerin artık sadece ekonomik açıdan değil, aynı zamanda politik ve kurumsal olarak da tanınmasıdır (MILLAN,1995:27).

Avrupa Birliğini Kuran Antlaşmaya kadarki Topluluk düzenlemelerinde Topluluğun, gözünü fazlaca üye devletlere diktiği ve bu yüzden de 'eyaletlere(bölgelere)-kör' olduğu yönünde getirilen eleştiriler, bu yeni Antlaşma'nın bölgeleri, üçüncü düzey olarak kabul etmesiyle değişmeye başlamıştır. Böylece sadece, politik gerçekler ve yurttaşların beklentileri hesaba katılmış olmamakta; aynı zamanda Topluluk içindeki merkezkaç güçler ile merkezcil güçler de daha uyumlu hale getirilmiş olmaktadır (SCHMIEDHUBER,1995:31). Çünkü, yurttaşa yakınlık ve "aşağıdan yukanya" bir Avrupa Birliği'nin kurulması Maastricht Antlaşması'nın önemli bir öngörüsüdür. Kuşkusuz bu olumlu bir gelişmedir; çünkü, ortak bir Avrupa'nın oluşturulmasına eyaletlerin, bölgelerin, belediyelerin dahil olması insanların kimliği açısından büyük rol oynamaktadır (http://www.nlpb.de , 2000). 
Maastricht Antlaşması'na kadar 'bölgeler'ce gerçekleştirilen ve söz konusu Antlaşma'nın şekillenmesini etkilemeye yönelik girişimler, maddeler halinde aşağıdaki gibi özetlenebilir (HIERL,1995:89):

- 27 Ekim 1987'deki Münih Başbakanlar Konferansı,

- Başbakanlar Konferansı başkanı Josef Straus'un çağrısı üzerine, 11 eyalet başbakanının, Komisyon başkanı Jacque Delors ile 19 May1s 1988'de Bonn'daki Bayern temsilciliğindeki 'Birinci Buluşma',

- Bayern başbakanı Streibl tarafından öncülük edilen, 5 Avrupa Bölgeler Konferansı'nın (Münih, Brüksel, Linz, Riva del Garda ve Hannover) istekleri,

- Avrupa Bölgeler Meclisinin (Versammlung der Regionen Europas-VRE)'nin kararları.

Avrupa Topluluğu çerçevesinde genel olarak geçerli olmayan, tersine sadece işlevsel olan bir 'bölge' kavramının bulunduğu ve Topluluğun, 'bölgeler'in tanımını ve özellikle onların yetkilerle donatılmasını üye devletlere bıraktığı belirtilerek; Topluluğun, federal olmayan bir yapıyı ve belirli bir biçimde mülki bölümlenmeyi hiçbir zaman öngörmeyebileceği vurgulanmaktadır (SCHMIEDHUBER,1995:39). Eğer Topluluk, bölgeler şeklinde homojen alt bölümlemeler öngörüyorsa, bunun yönetim tekniği ve istatistiksel nedenlerinin bulunduğu ve bu gruplandırmada mümkün olduğunca var olan yönetsel bölümlemelerin, üye devletlerin ülke-içi hukukuna göre dikkate alındığ 1 ifade edilmektedir.

Aralık 1991'de kararlaştırılan ve Şubat 1992'da imzalanan Avrupa Birliğini Kuran Maastricht Antlaşması, her üye devlet arasındaki farklılığa karşın, özellikle bu ülkelerin mülki (territorial) yapıları ve ulus-altı birimlerinin hukuksal ve politik nitelikleri açısından var olan farklılık karşısında, bölgelerin bütün isteklerini gerçekleştirememiştir. Bununla birlikte, bölgelerin düşüncelerinin bir kısmını benimsemek ve antlaşmaya bağlamak suretiyle Maastricht Antlaşması, gerçekleşen düzenlemeleriyle bölgelerin istek ve önerileri bakımından bir çıkış noktası göstermektedir (HRBEK/WEYAND,1994:118). Şimdiye kadar Avrupa Topluluklan'nın üçünün kurucu antlaşmalarındaki haklar ve görevler, resmen sadece üye devletleri ilgilendirmekteydi. Bu yüzden bölgelere, şimdiye kadar eğer Topluluk işlerine ilişkin olarak iç-hukukça yetkilendirilmişlerse, sadece ülke-içi irade oluşum sürecine katılım yolu kalıyordu (SCHMIEDHUBER,1995:35). 


\section{BIRLIK ANTLAŞMASI'NCA BÖLGELERIN KURUMSAL SAPTANMASI}

1992'de imzalanan ve Avrupa Birliğini kuran Antlaşma, Kasım 1993'de yürürlüğge girmiştir. Bu Antlaşma ilk defa bölgeleri -Alman eyaletlerinin öncü girişimleri sonucu (TAURAS,1996:31) -, üye devletlerin birer politik-yönetsel aktörleri olarak birincil (en üst) hukukun içine dahil etmiştir. Bu gelişmenin, diğer bir deyişle, bölgelerin güçlü bir şekilde varlığının kabullenilmesi ve Topluluk karar alma ve politikalarını saptanmasında katılımcı birimler haline gelmesi ve teknokratik görüntüyü aşan, politik yetkiye sahip birimler olarak öngörülmesinin temelinde bölgelerin bu güne kadarki girişimlerinin bulunduğu ifade edilebilir (PUJOL,1995:54). Bölgeler açısından burada en önemli değişiklik, Topluluk Antlaşması'nın 146. maddesiyle 'Füzyon' Antlaşması (8 Nisan 1965 tarihli Avrupa Topluluğu Ortak Komisyon ve Ortak Konseyinin Kuruluşu Antlaşması)'nın yeniden kaleme alınması ve ayrıca Topluluk Antlaşması'nın 198a-c maddesi ile "Bölgeler Komitesi"nin kurulmasıdır (THEISSEN,1996:40). Böylece, Antlaşma'nın formüle edilmesi öncesinde ortaya konan, bölgesel çıkarların temsili isteklerinin hepsi olmamakla birlikte, kimileri yerine getirilmiştir. Maastricht Antlaşması ile getirilen ve politik bölgeler için öneme sahip kurumsal yenilikler aşağıda açıklanmaktadır (PINTARITS, 1996:94):

\section{Yerellik Illkesinin (Subsidiaritaet) Kabulï}

Yerellik ilkesi, kapsayıcı bir yapılanma ilkesi olarak Antlaşma'ya dahil edilmiştir. Avrupa Topluluğu, Topluluk Antlaşması'nın (Europaeische Wirtschaft Gemeinschaft-EGV) 3-b maddesi 2.paragrafina göre sadece, "paylaşlan yetkililik" (konkurrierende Zustaendigkeit) alanlarında "ïye devlet ulusal düzeyinde dikkate alınan önlemlerle, amaçlara yeterince ulaşılmadı̆̆ taktirde ve ulaşllmadığl sürece ve bu nedenle, ilgili eylemin kapsam ya da etkililik açısından Topluluk düzeyinde daha iyi gerçekleştirilebilecek olduğu" durumlarda görevlidir. Ayrıca Topluluk önlemlerinin de "mutlaka gerekli ölçüyü aşamayacak şekilde olması" istenmektedir.

\section{Avrupa Birliği Bakanlar Konseyi'ne Bölgelerin Katılımı}

Anayasal düzenleri federal bir şekilde düzenlenmiş Topluluk üye devletlerinin eyalet ve bölge bakanlan, bütün bir devlet için bağlayıcı görüşler vermeye yetkili olmaya başlayınca, gelecekte Bakanlar Konseyi'nde devletlerini temsil edilebileceklerdir ( EGV mad.146). Bu maddeye göre, her üye devlet, zorunlu olarak kendi ulusal hükümeti lehine bir tutum içinde olacak bakan düzeyinde bir temsilcisini Konsey'e gönderebilecek; bu temsilci bir bölge mensubu da olabilecektir. Ancak burada bir bölge mensubunun gönderilmesinin zorunlu olarak öngörülmediği, sadece bir olanak olarak 
düzenlendiği ve uygulamada daha çok bir istisna oluşturduğu ileri sürülmektedir (THEISSEN,1996:41).

\section{Bölgeler Komitesi (Ausschuss der Regionen-AdR)}

Yeni bir Topluluk kurumu olarak "Bölgeler Komitesi"nin oluşturulmasıyla bölgelerin, Topluluk karar sistemine kurumsal bir biçimde katılım istekleri, benimsenmiş olmaktadır. Böylece ilk defa bölgelere, bütünleşme sürecine katılma yolu açılmıştır (LIPPERT,1998a:359). Bölgeler Komitesi, bir Topluluk organı sayılmayabilir; daha çok, Bakanlar Konseyi ve Komisyon ile uyumlu hale getirilmiş, danışma işlevine sahip bir kurum olarak tanımlanabilir (HRBEK / WEYAND,1994:125). Bu Komite'de, kendine özgü yetkilere ve karar alma organına sahip gerçek bölgeler yanında, az sayıda üye devlet de bulunduğu için, bölgesel düzeyin temsiliyle sınırlı kalmadığı, aynı zamanda yerel düzeyi de temsil ettiği söylenebilir (SCHMIEDHUBER, 1995:36).

Bölgeler Komitesi hakkındaki 198-a ve c maddelerinde içerilen Antlaşma hükümleri göstermektedir ki, bu yeni organa sadece ikincil roller tahsis edilmiştir. Bölgeler Komitesi'nin Topluluğun diğer üç organı olan Komisyon, Bakanlar Konseyi ve Parlamento ile beraber güçlü bir politik ortak olarak gelişip gelişemeyeceği ve Topluluk işlerine ilişkin kararları kesin bir şekilde etkileyip etkilemeyeceği, bir dizi etkenlere bağlı olarak zaman içinde belirginlik kazanacaktır.

\section{BÖLGELER KOMITESININ KURULUŞU, BILEŞIMI, YETKI VE GÖREVLERI}

\subsection{Bölgeler Komitesi'nin Kuruluşu}

Aralık 1991'de Maastricht'te danışma işlevli bu Bölgeler Komitesi'nin kurulması, ister devlet biçiminde isterse yerel yönetim biçiminde olsun, bölgelerin gelecekte Brüksel'de Birlik organlarının önemli bir muhatabı olarak yerini alacak olması dolayısıyla, "dev bir adım" olarak değerlendirilmektedir (KNEMEYER / HEBERLEIN,1994:89). Özerk bir organ olarak Bölgeler Komitesi'nin kurulması, ademi merkezi yönetim birimlerinin, Avrupa'nın bütünleşmesi için anlamlı bir unsur olduğunun kabul edildiği önemli bir adımdır (MILLAN,1995:28). Şimdiye kadar yerel yönetimler özellikle Avrupa Belediyeler ve Bölgeler Kongresince, bölgeler ise, çoğunlukla Avrupa Bölgeler Meclisince temsil edilmişlerdi. Mart 1994'te Bölgeler Komitesi'nin örgütlendirilmesiyle (BOCKLET,1995:135), Topluluk ve üye devletler ikili düzeyinden oluşan mevcut dikey yapılı Topluluğa, üçüncü bir düzey eklenmiştir. Böylece AB'nin 'eyalet körlügü'nün kesin bir şekilde aşıldığı ve yurttaşa daha yakınlık yönünde büyük bir adım atıldığı ifade edilmektedir 
(GOPPEL, 1995:8). Bu düzey, her üye devlette devlet düzeyinin altında bir düzey olarak öngörülmekteydi. Bu düzeyi üye devletler, kendi farklı yapıları ve farklı kamu hukuksal düzenleri doğrultusunda kendileri belirleyeceklerdir. $\mathrm{Bu}$ düzey, kimi üye ülkelerde eyalet iken, kiminde bölgelerdir.

Burada, eyalet veya bölgeye sahip olmayan üye ülkelerdeki durumun nasıl belirleneceği sorusu gündeme gelmektedir. Çünkü örneğin, Luxemburg ya da Danimarka gibi ülkeler, "bölge" kavramına" karşıllı gelebilecek yönetim düzeylerine sahip değildirler. Bu tür ülkelerde öncelikli düzey, yerel yönetimler düzeyi olmaktadır. Bu tür bir düzenlemenin temelinde, yerel yönetimlere de Bölgeler Komitesi yolunun açılması sağlanarak, kamu yönetimlerinin yapılanmasında farklı biçime sahip devlet yapılarını da, bunların "bölgeselleşmesine gerek kalmadan", yeni düzenlemeyle uyumlu hale getirme isteği bulunduğu ileri sürülmektedir (DECKART,1995,171). Danışma işlevli olmasına rağmen bu Komite, Bakanlar Komitesi'nin ya da Komisyon'un isteği üzerine, bölgesel gelişme veya bölgesel çıkarlara ilişkin sorunları bölgesel sonuçlan ile beraber gündeme getirebilecektir. Ayrıca şu alanlarda görüş bildirme hakkına sahiptir (LAEUFER,1995:204-212; PINTARITS, 1996:95). Genel ve mesleki eğitim ve gençlik (126. mad. 4.pragraf), kültür, kamu sağlı̆̆ı, trans-Avrupa Ağlan (Transeuropaische Netze), ekonomik ve sosyal uyum, Avrupa bölgesel fonları, yapısal fonun ve uyum fonunun verimliliği (mad.130b ve $130 \mathrm{~d}$ ).

Bunlardan daha önemlisi, Komisyon ya da Bakanlar Konseyi'nin bilgisi çerçevesinde Bölgeler Komitesi doğrudan bütün Birlik sorunlarıyla ilgilenebilir. Komite, 15 üye devletin yerel ve bölgesel düzeylerini temsil etmektedir. Bu üyeler 4 ylllık için gönderilirler. Bölgeler Komitesi ilk toplantısını Mart 1994'te yapmıştır. Üyeler ve aynı sayıdaki yetkili memurlar (yardımcılar), ilgili devletin önerisi ile Bakanlar Komitesi tarafından oybirliği ile atanmaktadır. Komite'nin 1996'daki birleşimine, yalnızca Belçika sadece bölgesel temsilciler göndermiş; buna karşın Danimarka, . Finlandiya, Yunanistan, İrlanda, Luxemburg ve Büyük Britanya sadece yerel yönetim düzeyinde temsilci göndermiştir (PINTARITS,1996:96).

Her ne kadar Topluluk Antlaşması'nda bu Komite'ye (danışma işlevine sahip olması ve görüş bildiren organ olması anlamında) sadece ikincil roller verilmişse de, olanaklar el verdiği ölçüde kısa sürede Komite'nin özgün bir nitelik ve eylem yeteneği kazanması gerektiği vurgulanmaktadır. Ancak

- Avrupa Birliği çerçevesinde "bölge" kavramlaştırması için, bkz; Mehmet ÖZEL, "Avrupa Birliği'nde Bölge, Bölgeselleşme, Bölge Yönetimleri Kavramlan Üzerine," AÜ.SBF Dergisi, 58-1,Ocak-Mart 2003, s. 97-117. 
çıkarlar konusundaki farklılıkların bu amacın hızla gerçekleşmesini zorlaştırabileceği ifade edilmektedir (HRBEK,1994:105).

\subsection{Bölgeler Komitesi’nin bileşimi}

Avrupa Birliği Antlaşması'nın 198-a maddesinin anlamından hareketle, "Bölgeler Avrupası"nın, gerçekte bir bölgeler ve yerel yönetimler Avrupası olduğu belirtilmektedir. Her ne kadar "Bölgeler Komitesi" şeklinde nitelendiriliyorsa da, komitenin bileşimi çerçevesinde bu madde öngörmektedir $\mathrm{ki}$, komite, bölgesel ve yerel yönetim temsilcilerinden oluşması gerekir. Şu halde "Bölgeler Avrupası"nda kentlerin ve belediyelerin yeri bölgelerin yanıdır. Bölgeler Avrupası'nın yerel yönetimler olmaksızın düşünülemeyeceği; bunların, yurttaşa yakınlığı somutlaştıran ve yerinden yönetimi ve yerelliği öne çıkaran bir Avrupa'da vazgeçilmez bir unsur olduğu belirtilmektedir (http://www.fbl.uni.siegen-de ,2000). Bununla birlikte, Bölgeler Komitesi'nin bileşiminin bu şekilde oluşmasının avantaj ve dezavantajlarından söz edilmektedir. Avantajı, neredeyse bütün ademi merkezi birimlerin bu Komite'de temsil edilmesi sağlanmakta ve böylece açıkça bir bölge yönetim birimine sahip olmayan devletleri de bir araya getirmektedir. Dezavantajı ise, Komiteye katılan sözkonusu çok sayıdaki yerinden yönetim birimlerinin amaçlarını ve çıkarlarını bütünleştirmekten çok farklılaştırarak, kendi bireyselküçük çıkarlarının peşine düşmeleridir. (Hesse, 1995-96:35).

Bölgeler Komitesi, Birlik içindeki değişik bölgelerden (eyaletler, bölgeler, özerk topluluklar), illerden (Provinz) ve yerel yönetimlerden gelen toplam 222 üyeden oluşmaktadır (Lippert,1998b:20). Komite üyelerinin ülkelere göre dağılımı Tablo-1'de gösterilmiştir.

Tablo: Bölgeler Komitesi üyelerinin üye devletlere göre dağılımı

\begin{tabular}{|c|c|c|c|c|c|}
\hline Üye Ülke & $\begin{array}{c}\text { Üye } \\
\text { Sayısı }\end{array}$ & Üye Ülke & $\begin{array}{c}\text { Üye } \\
\text { Sayısı }\end{array}$ & Üye Ülke & $\begin{array}{c}\text { Üye } \\
\text { Sayısı }\end{array}$ \\
\hline Almanya & 24 & Finiandiya & 9 & Isve & 12 \\
\hline Avusturya & 12 & Fransa: & 24 & 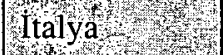 & 24 \\
\hline Belçika & 12 & Hollanda & 12 & Luxemburg & 6 \\
\hline B. Krallik & 24 & Irlandat & 9 & Porteky & 12 \\
\hline Danimarkas & 9 & Ispanya & 21 & Yunanistan & 12 \\
\hline
\end{tabular}

Kaynak: Laufer / Fischer, 1996:116 ve Deckart, 1995:171 
Komite üyeleri, Antlaşma'da da formüle edildiği gibi, herhangi bir direktife bağlı olmaksızın, Topluluğun yararına yönelik olarak, tamamen bağımsız bir şekilde görevlerini yerine getirirler. Bölgeler Komitesi'nin bileşimi temsil açısından homojen değildir; ayrıca burada çok çeşitli bölgesel çıkarların temsili söz konusudur. Meclis türü çalışmaların hepsinde olduğu gibi bu Komite'de de gruplaşmalar vardır (BOCKLET,1995:134). Bu gruplaşmalar, kimi zaman parti temelinde, kimi zaman çıkar esasına dayalı olabilmektedir.

\subsection{Yetki ve Görevler}

Komite, $A B$ Komisyonunun isteği üzerine toplanır ve toplantıya Komisyon başkanı çağrıda bulunur. Bunun dışında Komite kendiliğinden de bir araya gelme hakkına sahiptir. İç tüzükte daha yakından ele alınması gereken bu kural, kuşkusuz Topluluğun diğer organ ve kurumlan ile ilişkilerde Bölgeler Komitesi'nin bağımsız bir tutum ortaya koyması için bir başlangı̨̧ noktası oluşturmaktadır (HRBEK / WEYAND, 1994:129) .

Bölgeler Komitesi danışma işleviyle sınırlıdır (DECKART,1995:173; HRBEK / WEYAND,1994:129). Bölgeler Komitesi'nin görüş bildirmesi, Bakanlar Konseyi ve Komisyon için bağlayıcı bir karaktere sahip değildir. Bununla birlikte, görüş bildirme hakkının ihlal edilmesinin, ilgili hukuki işlemi ya da aracı, şekil açısından sakatlayacağı ifade edilmektedir (DECKART, 1995:175). Bakanlar Konseyi ve Komisyon, Komite'nin görüşünü dikkate almadıkları takdirde, niçin dikkate almadıklarını gerekçelendirmek; gerekçelendiremedikleri durumlarda, bölgelerin isteğine uygun olarak işlem yapmak durumundadırlar. Burada gerçekte Komitenin gücünün, politik ağırlığına göre ortaya çıkacağı söylenebilir.

\section{AB'NIN GELECEĞINE ILIŞKIN Bir DEĞERLENDIRME}

Avrupa Birliği'ni kuran Maastricht Antlaşması, bütünleşme sürecinde sadece bir aşamayı göstermektedir. Antlaşma'da belirlendiğgi şekliyle AB, her yönüyle tamamlanmış bir oluşum değildir. Bu Birlik, sadece bir antlaşma etrafinda birleşen 15'ler Topluluğu'nun durumunu göstermektedir. Bu haliyle Topluluğun, gelişmeye açık bir oluşum olduğu ifade edilebilir (HRBEK / WEYAND, 1994:153).

Avrupa Birliği'nin derinleşerek ilerlemesinin, Avrupa'nın gündemine değişmez bir biçimde oturduğu söylenebilir. Ancak, Avrupa Birliği'nin etkin bir şekilde gelişme gösterebilmesi için, Komisyon'un, içinde merkeziyetçi eğilimlere sahip olmayan bir bürokrasi mekanizmasının renk verdiği ve politik 
sorumluluğa sahip bir yönetsel organa dönüştürülmesi gerektiği; yasama etkinliğinin çok meclisli bir sisteme bırakılması (bu çok meclisli sisteme, yurttaşların gerçek temsilcisi olan Parlamento ile bölgelerin de dahil olduğu uye devletlerin temsilcisi olan Bakanlar Konseyi dahildir) ve bölgelerin ortak karar alan temsilci organı olarak Bölgeler Komitesi'nin geliştirilmesi önerilmektedir (STOIBER,1995:46).

Görüldügüü üzere bölgeler artık bir kavram, hatta danı̧ma niteliğinde de olsa bir kurum olarak uluslararası bir antlaşmada yer almıştır. Bunlar, kimi hukuksal düzenlemeler sonunda, yönetim hukukunda öngörülen kurallara uygun yerel yönetim birimlerine dönüştürülebilir (TOBB,1996:24). Aynca, Avrupa'da bölgesel bağlamdaki gelişmelerin sonucu olarak, "bölgeciler"ce ileri sürülen, "Brüksel'in, 'Bölgeler Avrupası' biçimindeki bir Avrupa yapılanmasının hayal olduğu biçimindeki tepkisel yaklaşımının" tutmadığı ve bunun bugünkü gelişmelerle bir ütopya olmaktan çıtığı, gerçek bir vizyon halini aldığı ve bölgelerin belirlediği birleşmenin, Avrupa'nın 'derinleşme' ve 'genişleme' biçimindeki bütünleşmesinden daha önemli olduğu vurgulanmaktadır (KRINN,2001).

İddia edilebilir ki, Avrupa Topluluğu bütünleşme süreci ve öncelikle de yapisal fon, merkezi düzeyde bir kavram olarak "bölge" düşüncesinin yaygınlaşmasına katkıda bulunmuş̧tur. Ancak bu düşünce, çok farklı örneklere göre ve çok farklı kurumsal bağlamlarda gerçekleştirilmeye devam edilmektedir (MARCOU,1998:74).

\section{BÖLGELER KOMITESININ GELECEKTEKI} GELISIMI

Avrupa Birliği Antlaşması, Bölgeler Komitesini kurarak, bölgelere Avrupa Birliği üzerinde birlikte-biçimlendirmede yeni olanaklar yaratmıştır. Bölgelerin politik etkide bulunma olanakları, her uye-devlete göre farklılık göstermektedir (http://www.alpeadriadonau.it, 2000). Bölgeler Komitesi'nin kurulmasıyla, bölgeleri ilk defa, antlaşmalar yoluyla Avrupa yasama sürecine dahil eden bir meclis oluşturulmuştur. Bu Komitenin, Avrupa Parlamentosu yanında, AB'nin yurttaşa yakınlığını yansıtması ve yerel ve bölgesel çıkarları ulusal ve Birlik düzeyindeki çıkarlarla uyumlaştırarak, "demokrasi açı̆̆ını" (Demokratiedefizit) kapatması beklentisi vardır. Çünkü bu komite, AB'nin politik sisteminde önemli bir federal unsuru ifade etmektedir (BOCKLET,1995:137). Ayrıca bu Komite'nin, görüşlerin aşağıdan yukarıya yansıtılmasında ve bilgilerin yukandan aşağıya aktarılmasında aracı olması gerektiği vurgulanmaktadır (MILLAN,1995:29). Diğer taraftan, Bu Komite'nin 
kurulmasıyla, Avrupa Birliği'ne yönelik, 'merkeziyetçileşme' suçlamalarına yanıt verildiği belirtilmektedir (KRAETSCHELL / RENNER, 1995:26).

Maastricht Antlaşması'nın düzenlediği Bölgeler Komitesi olumlu bulunmakla birlikte, bu Komite'nin verimliliğini ve uygulamasını sınırlayan boşluklar bulunduğu belirtilmektedir (PUJOL, 1995:58). Buna göre;

1. İlk olarak; Komitenin bileşiminin, bölgesel ve yerel yönetimleri içerecek şekilde düzenlenmesi nedeniyle bir boşluk vardır. Komitenin adı 'Bölgeler Komitesi' olmasına rağmen Maastricht Antlaşması, yerel ve bölgesel yönetim temsilcilerinden oluşan bir organ öngörmektedir. Böyle bir düzenlemenin, yönetimde merkeziyetçi yaklaşımlar altında yeterince sıkıntı çekmiş bölgeleri, belediyeleri, Avrupa bütünleşme sürecinin kendilerine getireceği zorlukları kısmen aşabilmek dışında bir şey sunmadığı ifade edilmektedir.

2. İkinci boşluk, Bölgeler Komitesi'nin Ekonomik ve Sosyal Komite ile çok sıkı bir bağ içinde yapılandırılmasıdır. Bir ek-protokolde, bu iki komite için ortak bir örgüt yapısı öngörüldüğü belirtilmekte ve bu iki komitenin tamamen farklı çıkarları ve alanları temsil ettiği ifade edilmektedir. Dolayısıyla bu iki farklı çıkar örgütü, birbirinden bağımsız olarak konumlandırılmalıdır.

3.Üçüncü olarak; yetkiler açısından bir boşluk bulunmaktadır. Komiteye, bütün çıkarlarını veya yetkilerini ilgilendiren ķonulara yayılmış genel nitelikli bir danışma işlevi öngörülmemektedir; burada sadece ya antlaşmalarca açıkça öngörülen ya da Ekonomik ve Sosyal Komite'nin raporlarında bulunan durumlarda danışma işlevi bulunduğu ifade edilmektedir.

Bölgeler Komitesi'nin, $\mathrm{AB}$ düzeyinde henüz 'az sevilen bir çocuk' (HIERL,1995:90), diğer bir deyişle, henüz yaygın bir kabule mazhar olmamış yeni bir kurum olmasına rağmen, 1996'da başlatılan Avrupa Birliği Antlaşması'na Dair Revizyon Görüşmeleri (Hükümetlerarası Konferans)'nden itibaren AB'de Bölgeler Komitesi'nin haklarının genişletilmesi söz konusu edilmektedir. Buna göre, 20 Nisan 1995'deki Bölgeler Komitesi genel kurulunda kararlaştırılan görüşlerin, Maastricht Antlaşması'nın revizyonunu "pragmatik bir şekilde yönlendiren" bir "İstekler-Kataloğu" oluşturduğu belirtilmektedir (THEISSEN,1996:279).

$\mathrm{Bu}$ "İstekler Katalogu", Komiteye özellikle bir organ statüsü tanımayı öngörmekteydi. Ayrica Komite, kendi görevlerini gerçekleştirirken Komisyon ile beraber işbirliği yapabilecektir. Komitenin görüşleri, Avrupa Parlamentosu'na da gönderilecek; görüş ayrilıkları durumunda organlar, tutumlarının gerekçesini Komiteye bildirmekle yükümlü olacaklardı. Bu "İstekler Kataloğu"nun 173. maddesinde, Komitenin yetkilerinin kullanılması ve yerellik ilkesine aykırılık dolayısıyla dava açma hususunda sahip oldukları 
haklarının kesinlikle genişletilmesinin zorunluluğu vurgulanmaktadır. Bunun yanında, yine ilgili kataloğun söz konusu maddesine göre, "yasama yetkileri" bir talimatnameyle, bir yönetmelikle ya da bir kararla ihlal edilen bölgeler, iptal davası açmaya yetkili kılınmaktaydılar.

Bölgeler Komitesi'nin etkinlik şansını değerlendirmek gerekirse; ulusaltı düzeylerin çeşitliliği, Komitenin daha güçlü bir etkiye sahip olmasını engellemektedir. Ayrıca, ulus-altı birimlerin, bütün bir bölgesel alanı kapsamadaki temsil eksikliği dolayısıyla ortaya çıkan "mülki bir bölümleme olarak bölgesel meşruiyetteki eksiklik", en azından kimi ülkeler için, Bölgeler Komitesi'ni, üç düzeyli bir Avrupa yapılanması biçimindeki amaçlarını gerçekleştirme mücadelesinde zayıflatmaktadır (PINTARITS, 1996:96). Şu anda, gelir dağılımını düzeltici (redistributiv) bölgesel- ve uyum (kohaesion) politikaları gibi, Bölgeler Komitesi'nin temel yetki alanlarında ve aynı zamanda $\mathrm{AB}$ 'nin diğer bütün düzenleme alanlarında da, bölgeler arasında rekabetsel bir durum öne çıkarılmaktadır. Buna karşın, Bölgeler Komitesi'nde karar alma olanakları Bakanlar Komitesi'ndekine göre daha azdır; çünkü Komitenin ulusal düzeyde ve yönetimler arası düzeyde etkin olacak eşgüdüm mekanizması bulunmamaktadır.

"Bölgeler Avrupası" düşüncesinin gerçekleşebilmesi için, Maastricht Antlaşması doğrultusunda federalizm ve "yerellik ilkesi”nin güçlendirilmesine yönelik Avrupa düzeyinde yürütülen eylemlerin anlamlı bir sonuca ulaştırılması gerekir. Özellikle Bölgeler Komitesi'nin, uzun vadede AB yasama sürecinde gerçek bir üçüncü meclis olarak yeniden ele alınması; bu amaca yönelik olarak da, Bölgeler Komitesi'nin, yeterli düzeyde bir örgütsel yap1 yanında, hem kendine özgü bir 'girişimde bulunma' hakkına ve hem de kararlara katılma hakkına sahip olması önerilmektedir (GOPPEL, 1995:14).

1 Ocak 1993 tarihinde Tek Pazar'ın kurulması Avrupa'da kaçınılmaz olarak bir takım sonuçlar doğurmuştur. Bu sonuçlar zengin bölgeler ile diğerleri arasındaki uçurumu artırabilir. Çünkü kişilerin, malların, hizmetlerin ve sermayenin dolaşımının liberalleşmesinin, zengin ve dinamik bölgelerin avantajını daha da artırabileceği ileri sürülmektedir. Bu sorunun çözümü sürecinde, Toplulukça 1968 'den beri Topluluk politikalarının en iyi uygulayıcısı kabul edilen bölgeler için Bölgeler Komitesinin bir 'çekim noktası' olabileceği vurgulanmaktadır (BLANC,1995:163).

Diğer taraftan, bölgelere bölümlenmenin, kültürlere ve bölgelere göre farklılık gösteren bir çok Avrupalı anlayışın ve dünya görüşünün tanınması olanağını doğuracağı belirtilmekte ve Avrupa federalizminin, bu yüzden, içinde çeşitliliğin olanaklı olduğu bir Avrupa toplumu için şu anda bir gereklilik olduğu ileri sürülmektedir (http://userpage.fu-berlin.de , 2001). Çünkü, bölge 
çekirdeğinde bir Avrupa yapılanması, Avrupa'nın kültürel kalıtına, kültürel ve bölgesel farklılıklara saygı açısından, sadece ulus-devlet temelinde bir yapılanmaya göre daha uygun düşebilir. $\mathrm{Bu}$ arada, Bölgeler Avrupası programının, kültür şovenizmi ve kısmi ekonomik çıkarlarca ayakta tutulduğu şeklinde eleştirildiğini de belirtmek gerekir (DIETL,2000).

1997'deki Amsterdam Zirvesi'nde kararlaştırılan Kurucu Antlaşmalardaki değişikliklerin esas amacı, temel alanlarda AB'nin hareket yeteneğini iyileştirmekti. $\mathrm{Bu}$ temel alanlar özellikle adalet ve içişlerinde işbirliği ve ortak dış ve güvenlik politikasını içermekteydi. Ayrıca AB'nin, "genişleme" için hazırladığı kurumsal düzeltimleri (reformları) güvence altına almak da bu zirvenin temel amaçlarındandı (LIPPERT,1998b:11). Haziran 1997'deki Amsterdam Antlaşması'na götüren 1996/97 Hükümetler Konferansı'nda eyaletler ve bölgeler, Avrupa Parlamentosu yaninda Amsterdam Zirvesinin karlı çıkanlarından olmuşlardır. Çünkü bunlar, yeni bir "yerellik ilkesi protokolü" ve Bölgeler Komitesi'nin örgütsel bağımsızlı̆̆ gibi "federal" yapıyla ilgili konularda başarılar elde etmişlerdir (HUTTMANN/ KNODT, 2000:35). Bölge ve eyaletler, 2000 Hükümetler Konferansı (Nice Sözleşmesi) bağlamında da, Avrupa Komisyonu başkanı Romano PRODİ'den Aralık 2000 Nice Zirvesi'de AB, üye-devletler ve bölgeler arasında yetkilerin açık bir şekilde belirlenmesini istemişlerdir (HUTTMANN/KNODT,2000:35).

\section{SONUÇ YERINE}

Belirtmek gerekir ki, bugün Avrupa Birliği çerçevesinde "Bölgeler Avrupası", "Yurttaşlar Avrupası", "Bölgelerle Avrupa" gibi bir çok kavram geliştirilmiştir. Bütün bunlar ve bu zamanın gelişen eğilimleri dikkate alındığında, bütünleşmiş bir Avrupa istenmediği; tersine daha çok Avrupa'nın bölgeselleşmesinin istendiği ileri sürülmekte; daha doğru bir anlatımla, bütünleşmenin sadece "ulus-devlet"e dayandırılmasının yeterli olamayacağı önemli bir biçimde vurgulanmaktadır. Ancak, günümüzde daha çok "Bölgeler Avrupası"ndan söz edildiği halde bölgelerden çok farklı birimlerin anlaşıldı̆̆ (örneğin, kimi zaman "Bezirk" (saha, bölge), "Gegend" (çevre), kimi zaman Provinz (il, 'taşra') anlamına geldiği belirtilmektedir (HARTMANN,1994:10). Bu durumda da günümüzde "bölge" kavramını açılamaya çalı̧̧an bütün uğraşıları ve tanımlama girişimlerini ya da politik-yönetsel tekniklerce belirlenmiş ölçütleri yeğlemek kolay olmamaktadır (KANNONIER,1999). Şu halde bir "Bölgeler Avrupası"nın gerçeklik kazanması ve Avrupa Birliği'nin üç düzeyli bir yapıya ulaşması için, öncelikle bütün Avrupa kurumlarından yurttaşlara kadar her birimde bölge kavramının, tek bir anlama gelecek şekilde netleştirilmesi gerekmektedir. Burada bir "bölge" tanımlaması yapmak 
gerekirse; "daha büyük politik birimler çerçevesinde ve aynı zamanda bunların çatısı altında güçlü bir özerk yaşam sürdüren; eski devlet işlevlerinin bir çoğunu bu mekansal birim içerisinde yerine getiren politik mekansal birimler" (HARTMANN,1994:11) şeklinde, politik-yönetsel bir tanımlama yapılabilir.

Belirtile gelindiği üzere, bölgelerin temel isteği, Topluluğun şimdiye kadarki iki basamaklı yapısının oluşturduğu eksikliği giderme, diğer bir ifadeyle bölgelerin, bağımsız üçüncü bir düzey olarak resmen tanınması yönünde idi. Burada savunulan temel düşünce; eğer demokratik bir Avrupa, diğer bir deyişle, yurttaşların genelinin Avrupa'sı olarak anlaşılacak ve kabul edilecek bir Avrupa kurulmak isteniyorsa, bu takdirde yurttaşa en yakın politik iktidar düzeyleri olan bölgelerin Avrupa'nın bütünleştirilme çabalarına dahil edilmesi önerilmektedir. Bölgelerin katılımının, Topluluğun demokratik meşruiyetini artıracağı vurgulanmaktadır (PUJOL, 1995:56).

"Üçüncü düzey" olarak adlandırılan bölgesel düzeyin oluşturulmasının, $\mathrm{AB}$ ile üye devletler yanında bölgelerin bağımsız ve kendine özgü bir şekilde gelişmesine olanak vereceği; ancak bunun için de, her bir üye devlette federalleşme yönünde geli̧̧menin olması gerektiği ileri sürülmektedir (BOCKLET,1995:137). Diğer taraftan, bölgeler, ancak gerçek anlamda hiç kimsenin görmezden gelemeyeceği bir aktör olduğunda, bağımsız bir üçüncü düzeyin hukuken kurulması sorunu, somut bir şekilde ortaya konacaktır. Bu şekilde bir gelişme gösterecek olan bir "Uluslar- ve Bölgeler Avrupası"nın, kendisinin devlet benzeri yapılarına rağmen, bir Avrupa Federal Devleti oluşturmayacağı ifade edilmektedir (STOIBER,1995:47). Çünkü bu Avrupa, sadece bölgeler ve uluslar tarafından kendisine açıç̧a tahsis edilmiş görevleri yerine getirmekte ve ayrıca bölgeler ve ulus-devletler, boyutunu ve süresini kendilerinin belirlediği bir yetki aktarımı yoluyla egemenliklerinin bir kısmını Topluluğa aktarmaktadırlar. Bununla birlikte, Maasricht Antlaşması'na dayalı düzenlemelerin, Topluluk içindeki küçük üye devletlere daha uygun düşmesi (SCHMIEDHUBER,1995:37), Birliğe egemen olan mantığın 'daha küçük birimlere doğru' olduğu şeklinde yorumlanabilir.

Diğer taraftan, "Bölgeler Avrupası" çerçevesinde üretilen kimi düşüncelere dikkat çekilerek; bölgelerin hak isteğinde bulunmalarının, ulusal devletlerin zararına işletilmemesi gerektiği; bunun yüzyıllar öncesine, Feodal sisteme, "Baronlar Avrupası"na doğru bir adımı ifade edeceği ileri sürülmektedir (BLANC,1995:162). Bu yaklaşıma göre, Avrupa'nın iskeletini devletler oluşturmalıdır; ancak bu iskelete et de eklemlemek gerekir ki, bu da bölgelerdir. Diğgr taraftan, "Bölgeler Avrupası" boyutundan hareketle Avrupa bütünleşmesini esas almanın, Avrupa'nın birleşmesi ve (Avrupa'nın) federalizm (boyutunda) gelişmesi amaçları açısından sadece yararlı olabileceği vurgulanmaktadır (KALBFLEISCH / KOTTSIEPER,1995-96:140). 
Bölgeler, kendilerine özgü ve mikro ekonomik denebilecek yetkilerini, kendi topraklarındaki ekonomik birimlerin rekabet gücünü geliştirme koşulları çerçevesinde daha etkin bir şekilde yerine getirebilirler. Bölgesel düzeydeki mesleki eğitim, arazi kullanım politikası, şehircilik (kentsel planlama) (Staedtebau), araştırma, teknolojik gelişme gibi alanlarda bölgelerin yetkili kılınması, Topluluk düzeyinde alınan makro ekonomik kararların daha etkinleşmesi olană̆ını artıracaktır; böylece bölgelerin, rekabet gücüne sahip, teknolojik ve ekonomik gelişmenin yapılandırıldığı bir bölgeye dönüşmesi sağlanmış olur. Çünkü bölgeler, ekonomik gelişme ve mekan düzenleme politikalarının uygulanmasında en uygun büyüklüklerdir (BLANC,1995:167).

Sonuç olarak A. Toffler'ın ifadesine katılarak şu söylenebilir: “Avrupa'nın geleceği, Brüksel ile üye devletler (ve uluslar) ve bölgeler arasındaki denge tarafından belirlenecektir." (PUJOL,1995:53).

\section{Kaynakça}

BLANC, Jacques (1995), "Aufgaben und Herausforderungen für den Ausschuss der Regionen," HIERL, H. (hrsg.), Europa der Regionen (Bonn: Economica Verlag): 157-170.

BOCKLET, Rheinhold (1995), "Der Ausschuss der Regionen - Ein parlamentarisches Gremium mit Wechselnden Mehrheiten," HIERL, H. (Hrsg), Europa der Regionen (Bonn: Economica Verlag): 134-139.

DECKART, W. C. (1995), "Die Deutschen Laender nach Maastricht-Mitgliedschaft im Ausschuss der Regionen-Beteiligung an der Rechtsstzung der Europaeischen Union," HIERL, H. (Hrsg), Europa der Regionen (Bonn: Economica Verlag): 170-186.

DIETL, Andreas (2000), "Regionalstaaten im Wettbewerb," http://www.nadir.org/nadir/ periodika/jungle_world/_2000/37/07ahtm, 13.12.2000.

ERBAY, Yusuf/ YENER, Zerrin (1998), "Sinır-ötesi Iş̧birliği:Türk Yerel Yönetimleri iç̧in Yeni bir Açılım," Çağdaş Yerel Yönetimler (Cilt 7, Sayı 2):11-25.

http: / / www.nlpb.de/10-them/10-themeurop-union/10them-europ-union04.htm, EUROPA: "Einführung-Europaeische Union," 12.12.2000.

(2000),

http: //www.nlpb.de/10-them/10-themeurop-union/10them-europ-union04.htm, EUROPA: “Europa der Regionen," 12.12.2000.

(2000),

GERSTL, Wolfgang (1999), "Wien- Zentrum einer Region," http://www.wienerjournal.at/ STADTO6.HTM, 13.03.1999.

GOPPEL, Thomas (1995), “Die regionale Dimensionen der Europaeischen Einigung," HIERL, $\mathrm{H}$. (Hrsg), Europa der Regionen (Bonn: Economica Verlag): 3-16.

HALLIGAN, Christian (2001), "Europa der Vaterlaender," http://www.Isg.musin.de/ 10euroweb/vater-laender.htm, 12.01.2001.

HARTMANN, P. Claus (1994), "Regionen in der Frühen Neuzeit - Model für ein Europa der Regionen?," HARTMANN, P.C. (Hrsg), Regionen in der Frühen Neuzeit (Berlin: Dunker und Humblot): 9-20.

HESSE, Joachim Jens (1995-96), "Die Begleitforschung zum Ausschuss der Regionen der Europaeischen Union," HESSE, Joachim Jens (Ed.), Regionen in Europa-Regions in Europe-Regions en Europe I (Baden-Baden: Nomos Verlagsgesellschaft 1. Auflage): 33-43. 
HIERL, Hubert (1995), "Die Informationsbüros: Wegbereiter und Wegbegleiter des Ausschusses der Regionen," HIERL, H. (Hrsg), Europa der Reginen (Bonn: Economica Verlag):8292.

HRBEK, R. I WEYAND, S. (1994), Betriff: Das Europa der Regionen- Fakten, Probleme, Perspektiven (München: Verlag C.H.BECK).

HRBEK, Rudolf (1994), "Der Ausschuss der Regionen," Jahrbuch der Europaeichen Integration, 1993/94 (Bonn: Institut für Europaeische Politik).

http://userpage.fu-berlin.de/-werwigk/seiten/europa-der-regionen.html (2001), "Politik der Vielfalt: Für ein Europa der Regionen," 10.01.2001.

http://www.alpeadriadonau.it/rivista/17/DE/02.asp?z=1 (2000), “Baden-Württemberg als europaeische Region," 12.12.2000.

http://www.fb1.uni-siegen.de/ifer/ir/di_text.htm (2000), "Das Europa der Regionen, eine Metapher für Dezentralitaet, Subsidiaritaet und Bürgernaehe," 13.12.2000.

http://www.spd-schleswig-holstein.de/jusos/themen/europa.htm (2000), "Leitfaden für die Europapolitische Diskussion," 13.12.2000.

HUTTMANN, Grosse Martin / KNODT, Michele (2000), "Die Europaeisierung des Deutschen Föderalismus," Politik und Zeitgeschichte, B 52-53: 31-38.

KALBFLEISCH-KOTTSIEPER, Ulla (1995/96), "Die Fortentwicklung des Föderalismus in Europa: Nur ein Anliegen der deutschen Laender?," HESSE, Joachim Jens (ed.), Regionen in Europa-Regions in Europe-Regions en Europe 1 (Baden-Baden: Nomos Verlagsgesellschaft, 1. Auflage):129-141.

KANNONIER, Reinhard (1999), "Postmoderner Regionalismus," http://www.fdr.at/fdr/fdr01/ Kannonier. Htm.

KELEŞ, Ruşen (1998), "Bölge Gerçeği ve Avrupa," Çağdaș Yerel Yönetimler (Cilt 7, Sayı 2):3-10.

KELEŞ, Rușen (1999), Avrupa'nın Bütünleşmesi ve Yerel Yönetimler (Ankara: TBD. ve KAV. Ortak Yayını).

KNEMEYER, Franz Ludwing (1994a), "Region-Regionalismus," KNEMEYER, F.L. (Hrsg.), Europa der Regionen-Europa der Kommunen (Baden-Baden: Nomos Verlagsgesellschaft, 1. Auflage):25-37.

KNEMEYER, F.L. (1994b), "Entwicklungslinien zu einem Europa der Regionen," KNEMEYER, Franz Ludwig (Hrsg.), Europa der Regionen-Europa der Kommunen (Baden-Baden: Nomos Verlagsgesellschaft, 1. Auf(age):11-25.

KNEMEYER, Franz Ludwig / HEBERLEIN, Horst (1994), “Der Ausschuss der Regionen," KNEMEYER, Franz Ludwig (Hrsg.), Europa der Regionen-Europa der Kommunen (Baden-Baden: Nomos Verlagsgesellschaft, 1. Auflage): 89-99.

KRAETSCHELL, H./ RENNER, G. (1995), "Politik und Wirtschaft: der Gemeinsame Markt," Informationen zur Politische Bildung, 213 (Bonn: Bundeszentrale für Politiache Bildung): $12-44$.

KRINN, Almut (2001), "Referat: Aspekte grenznaher Zusammenarbeit im Gebiet Baden/Elsass," http:// www.fhov-ludwigsburg.de/projekt/sem_arb/fb1/baden.htm, 10.01.2001.

LAEUFER, Thomas (Erarb.) (1995), Europaeische Union- Europaeische Gemeinschaft Die Vertragtexte von Maastricht (Bonn: Europa Union Verlag GmbH.).

LAUFER, Heinz / FISCHER, Thomas (1996), Föderalismus als Strukturprinzip für die Europaeische Union (Gütersloh: Verlag Bertelsmann Stiftung).

LAUFER, Heinz / MUNCH, Ursula (1997), Das föderatife System der Bundesrepublik Deutschland (Bonn: Bundeszentrale für politische Bildung).

LE GOOF, Jacques (1997), Die Geschichte Europas, Bundeszentrale für politische Bildung (Frankfurt/Main: Campus Verlag GmbH).

LIPPERT, Barbara (Eingeleitet) (1998a), Europa an der Schwelle zum 21. Jahrhundert-Reform und Zukunft der Europaeische Union (Bonn: Bundeszentrale für politische Bildung). 
LIPPERT, Barbara (1998b), "Europa 2000-Reform und Zukunft der Europaeichen Union," LIPPERT, Barbara (Eingeleitet), Europa an der Schwelle zum 21. Jahrhundert (Bonn: Bundeszentrale für politische Bildung): 9-45.

LUVERA, Bruno (2001), "Der neue Regionalismus- Von einem demokratischen Europa der Regionen zum ethnonationalen Föderalismus," http://www.oeko-net.de/kommune/ kommune6-96/tluvera.htm, 10.01.2001.

MARCOU, Gerard (1998), "Europaeische Integration und EU-Mitgliedstaaten," LÜEDER, Klaus (Hrsg.), Öffentliche Verwaltung der Zukunft (Berlin: Duncker \& Humblot): 59-87.

MILLAN, Bruce (1995), "Was erwartet die EU-Komission von der Arbeit des AdR?," HIERL, H. (Hrsg), Europa der Regionen (Bonn: Economica Verlag): 27-31.

ÖZEL, Mehmet (2003), “Avrupa Birliği'nde Bölge, Bölgeselleşme, Bölge Yönetimleri Kavramlan Üzerine," AÜ. SBF Dergisi, 58/1: 97-117

PINTARITS, Sylvia (1996), Macht, Demokratie und Regionen in Europa (Marburg: Metropolis Verlag).

PROBST, Klemens (1994), Regionale Selbstverwaltung: Die bayerische Bezirke als Model für ein bürgernahes Europo (München: WF.).

PUJOL, Jordi (1995), "In Richtung eines Europas der Regionen?," HIERL, H. (Hrsg.), Europa der Regionen (Bonn: Economica Verlag): 48-60.

RAICH, Silvia (1995), Grenzüberschreitende und Interregionale Zusammenarbeit in einem "Europa der Regionen" (Baden-Baden: Nomos Verlagsgesellschaft).

SCHMIDHUBER, Peter M. (1995), "Europa der Regionen - statt Beobachtung Mitgestaltung," HIERL, H. (Hrsg), Europa der Regionen (Bonn: Economica Verlag): 31-42.

STOIBER, Edmund (1995), "Europa im Umbruch," HIERL, H. (Hrsg), Europa der Regionen (Bonn: Economica Verlag): 42-48.

TAURAS, Olaf (1996), Der Ausschuss der Regionen - Institutionalisierte Mitwirkung der Regionen in der EU (Kamen - Westf.).

TC. BAŞBAKANLIK (1999), Avrupa Birliği ve Türkiye (Ankara: Dış Ticaret Müsteşarlığı, 4. Baskı).

THEISSEN, Robert (1996), Der Ausschuss der Regionen (Artikel 198a-c EG-Vertrag) (Berlin: Dunker und Humblot $\mathrm{GmbH}$ ).

TOBB (1996), "Mahalli Idarelerin Yeniden Yapılandırılmasi," Yerel Yönetim Reformu Özel Ihtisas Komisyonu Raporu (Ankara). 